\title{
Somatotype Differences in Young Soccer Players: A Chronological Age-Based Approach
}

\author{
Diferencias de Somatotipo en Jugadores Jóvenes de Fútbol: \\ Un Enfoque Cronológico Basado en la Edad
}

Hrvoje Sivric ${ }^{1}$; Ante Rada ${ }^{2}$ \& Petra Mandic Jelaska²

SIVRIC, H.; RADA, A. \& MANDIC, J. P. Somatotype differences in young soccer players: A chronological age-based approach. Int. J. Morphol., 36(4):1275-1279, 2018.

SUMMARY: The aim of this research was to identify somatotype differences between different age categories of young soccer players. In accordance with the aim, a sample of 274 young soccer players was divided into three groups (beginners N1 = 48, pioneers N2 = 111 and cadets N3 = 115). Somatotypes were assessed using the Heath-Carter method. Reliability of the obtained data was satisfactory (technical error of measurement [TEM] range: 1.11-4.11, coefficient of variation [CV] range: 0.03-0.09). A one-way between-subjects ANOVA together with Bonferroni correction revealed significant differences between groups in all somatotype components. The results indicated that the youngest players had a more pronounced endomorphic component $(\mathrm{p}<0.05)$, which decreased with years of training, and the ectomorphic component became most evident in the pioneers, but then decreased again. In addition, with years of training, the mesomorphic component became less pronounced. The observed differences indicated the existence of nonlinear and complex interaction dynamics of somatotype components that are not only under the influence of soccer training but also growth and development. These results can contribute to understanding the interactions and dynamics of somatotype components of different generations of young soccer players. The results also provide relevant information necessary for the precise identification of morphological characteristics of young soccer players, as well as the modelling of the training process aimed at maximizing playing potentials and competitive outcomes.

KEY WORDS: Anthropometric characteristics; Morphology; Heath-Carter; selection.

\section{INTRODUCTION}

Body composition plays a fundamental role in sports performance, specifically in the physical status of athletes (Sedeaud et al., 2014; Hernández-Camacho et al., 2017). Because of its convenience, anthropometry is often used to fully understand an athlete's performance at various competitive levels (Mészáros et al., 2000). More precisely, to compete at the highest levels, soccer players are expected to possess certain morphological characteristics (Hazir, 2010). Excess fat mass acts as a dead weight in activities in which the body is lifted repeatedly against gravity. This excess weight has a deleterious effect upon general locomotion and soccer-specific actions, such as jumping to contest aerial possession of the ball. Athletes can only manage movements with muscles during matches or training. Therefore, it is much easier to manage movements with less fat mass and more lean mass. The fat-free component, which includes lean muscle mass and bone mineral mass, is important for the production of speed, strength and power, and injury prevention (Arden \& Spector, 1997; Karlsson et al., 2003; Sutton et al., 2009). The amount of body fat is also used both as an indicator of being healthy and as one of the most important criteria of optimal efficiency in highperformance sports (Orhan et al., 2013). Studies with young soccer players have clearly indicated that physical characteristics are important indicators during identification and selection of talents (Gil et al., 2007a,b). Furthermore, anaerobic features are in some way related to the height and weight of athletes, particularly in young individuals and, in recent years, there has been a tendency to recruit taller and heavier players (Shephard, 1999).

A somatotype is defined as the quantification of the human body's shape and composition, and it is accepted as an indicator of physical body structure (Perroni et al., 2015). Furthermore, somatotyping, as one of the most frequently used techniques for analysing the body's build, has been

\footnotetext{
${ }^{1}$ College of Slavonski Brod, Dr. Mile Budaka 1, 35000 Slavonski Brod, Croatia.

${ }^{2}$ Faculty of Kinesiology, University of Split, Nikole Tesle 6, 21000 Split, Croatia.
} 
used to study many aspects of human biology, exercise and sports sciences, and it may be important in identifying talented young athletes for particular sports (Carter et al., 2005).

Although the importance of anthropometry is recognized in the selection process and training of soccer players, there is an evident lack of precise and accurate research of anthropometric characteristics in players (Gontarev et al., 2016). Furthermore, the contribution of physique and body composition in soccer performance has been recognized, but physical fitness variables have not been well studied in adolescent players (Nikolaidis \& Vassilios Karydis, 2011). Most scientific studies have been based on elite or professional soccer players, with a lack of research on young and non-elite soccer players (Gil et al., 2010).

Following above considerations, the aims of this research were to identify and compare somatotype differences between young soccer players who were divided into three chronological age-based groups: beginners, pioneers and cadets.

\section{MATERIAL AND METHOD}

Subjects. The sample consisted of 274 young soccer players (mean age: $12.98 \pm 0.49$ years; mean height: $166.17 \pm 13.32$ $\mathrm{cm}$; mean body mass: $54.20 \pm 12.66 \mathrm{~kg}$ ) who were divided into three age categories: beginners $(\mathrm{N} 1=48$; mean age: $10.06 \pm 0.08$ years; mean height: $145.98 \pm 6.83 \mathrm{~cm}$; mean body mass: $38.22 \pm 5.40 \mathrm{~kg}$ ), pioneers $(\mathrm{N} 2=111$; mean age: $13.62 \pm 0.65$ years; mean height: $165.15 \pm 9.57 \mathrm{~cm}$; mean body mass: $51.76 \pm 9.88 \mathrm{~kg})$ and cadets $(\mathrm{N} 3=115$; mean age: $15.26 \pm 0.75$ years; mean height: $17.59 \pm 7.40 \mathrm{~cm}$; mean body mass: $63.20 \pm 9.07 \mathrm{~kg}$ ). All participants' parents signed written consent forms and were fully informed about the purpose of the study. Research was conducted fully in accordance with the Declaration of Helsinki and approved by the institution's Ethics Committee. All players had an average participation of $7-10 \mathrm{~h}$ of training and competitive play per week.

Variables. With the purpose of calculating somatotype components (endomorphy, mesomorphy and ectomorphy) by the Heath-Carter method (Carter \& Heath, 1990), 10 anthropometric measures were assessed: body height $(\mathrm{BH})$; body mass (BM); triceps (SF_TRIC), sub scapular (SF_SUBSCA), supraspinous (SF_SUPSP) and calf (SF_CAL) skinfolds; flexed arm (GTH_FARM) and calf girth (GTH_CLF); and humerus (BRDTH_HUM) and femur breadth (BRDTH_FEM). Height was measured to the nearest $0.1 \mathrm{~cm}$ using a portable stadiometer (Holtain Ltd., Crymych,
U.K.), and body weight (BW) to the nearest $0.1 \mathrm{~kg}$ using an electronic scale (Tanita TBF 401A, Japan), with the participants not wearing shoes and wearing only training clothing. Skinfold measurements were measured to the nearest $0.2 \mathrm{~mm}$ using skinfold calipers (Holtain Ltd., Crymych, U.K.), while biepicondylar breadth was measured to the nearest $0.1 \mathrm{~cm}$ using a bicondylar caliper (Holtain Ltd, Crymych, U.K.), and limb girths were measured to the nearest $0.1 \mathrm{~cm}$ using a non-elastic tape (KaWe CE, Kirchner und Welhelm, Germany).

Experimental procedures. All measurements were taken by two experienced observers at the beginning of June during five consecutive days before training at approximately the same time of the day between 9:00 a.m. and 10:30 a.m., before training. Measurements were conducted in the dressing rooms off an air-conditioned hall, with an average temperature of $24{ }^{\circ} \mathrm{C}$. All participants participated in normal daily soccer trainings. All measurements were taken from the right side of the body by the same person, according to the procedures described in the Anthropometric Standardization Reference Manual (Lohman et al., 1988), and were performed three times by an experienced kinesiologist.

Statistical Analysis. Arithmetic means of the three measurements were used as the final result, and for every playing position the somatotype was calculated by the HeathCarter method. The data is presented as mean \pm standard deviation. The Kolmogorov-Smirnov test was used for normality assessment. For all variables, within-subject variability was assessed by a coefficient of variation (Hopkins, 2000), while the between-measurements reliability was assessed by a coefficient of intraclass correlation (ICC) and a one-way, within-subjects analysis of variance (ANOVA). Additionally, the technical error of measurement (TEM) was reported. To determine the significance of differences between the somatotypes of young soccer players, a one-way between-subjects ANOVA was applied. If the main effect appeared to be significant, a Bonferroni correction was applied. A partial eta-squared (partial h2) was used for the effect size assessment. Statistical analyses were performed using the data analysis software system Statistica 13.2. (Dell Inc., Tulsa, OK, USA). The type one error was set at $\mathrm{a}=5 \%$.

\section{RESULTS AND DISCUSSION}

The Kolmogorov-Smirnov test showed that, among the observed variables, only two variables had a mild deviation from normality $(\mathrm{p}<0.05)$, while all other varia- 
bles showed no significant deviations from a normal distribution $(\mathrm{p}>0.20)$. The TEM was lower than $5 \%$ for skinfolds and lower than $2 \%$ for the other measurements (Table I).

Descriptive statistics and reliability assessments of morphological variables of the overall sample of young soccer players are presented in Table I.

Table I shows that, due to a high age range (11-17 years), there is a relatively high variability in both the data for all anthropometric measurements and in the types of somatotype components. Furthermore, Table I shows the arithmetic means and standard deviations of the individual age groups in all three somatotype components, and the results of the $\mathrm{F}$ test and its level of significance.
Figure 1 shows that a group of beginners is ectomorphic-mesomorphic in structure, although the endomorphic component has a significant influence on the composition of their bodies. The members in the pioneers group are mesomorphic-ectomorphic in structure, but their endomorphic component is somewhat lower than the group of beginners. The third group, the cadets, is mesomorphicectomorphic, and although the ectomorphic component has no negligible influence, it is at the lowest level compared to the younger age groups.

Regarding endomorphy and mesomorphy, a one-way between-subjects ANOVA revealed a significant main effect $\left(\mathrm{F} 2,271=5.804, \mathrm{p}=0.003, \eta^{2}=0.041\right.$ and $\mathrm{F} 2,271=5.822$, $\mathrm{p}=0.003, \eta^{2}=0.041$, respectively). For both somatotypes, a Bonferroni correction revealed significant differences

Table I. Descriptive statistics of variables of morphological characteristics in young soccer players for overall sample (N = 274) of respondents $(\mathrm{M} \pm \mathrm{SD}$ - mean \pm standard deviation; $\mathrm{CV}$ - coefficient of variation; ICC - intraclass correlation; TEM\% - technical error of measurement; F - F test value; $\mathrm{p}$ - level of significance)

\begin{tabular}{lcccccc}
\hline Variables & $\mathrm{M} \pm \mathrm{SD}$ & $\mathrm{CV}$ & $\mathrm{ICC}$ & TEM\% & $\mathrm{F}$ & $p$ \\
\hline BH [cm] & $166.17 \pm 13.32$ & 0.04 & 0.99 & 1.63 & 1.76 & 1.23 \\
BW [kg] & $54.20 \pm 12.66$ & 0.05 & 0.99 & 1.11 & 2.44 & 0.13 \\
SF_TRIC [mm] & $8.88 \pm 2.77$ & 0.07 & 0.94 & 2.34 & 2.56 & 0.09 \\
sub scapular [mm] & $7.70 \pm 2.11$ & 0.06 & 0.89 & 2.66 & 0.14 & 0.87 \\
SF_SUPSP [mm] & $7.10 \pm 2.96$ & 0.04 & 0.94 & 4.11 & 1.08 & 0.34 \\
SF_CAL[mm] & $8.92 \pm 2.71$ & 0.05 & 0.94 & 3.56 & 2.33 & 0.19 \\
GTH_FARM [cm] & $6.07 \pm 0.53$ & 0.06 & 0.92 & 4.07 & 0.64 & 0.53 \\
GTH_CLF [cm] & $9.30 \pm 0.65$ & 0.08 & 0.96 & 3.92 & 0.92 & 0.33 \\
BRDTH_HUM [cm] & $26.33 \pm 3.23$ & 0.09 & 0.94 & 2.60 & 5.12 & 0.01 \\
BRDTH_FEM [cm] & $34.06 \pm 3.37$ & 0.03 & 0.94 & 3.00 & 0.66 & 0.51 \\
\hline
\end{tabular}

Legend: body height (BH); body weight (BW); triceps (SF_TRIC), sub scapular (SF_SUBSCA), supraspinous (SF_SUPSP) and calf (SF_CAL) skinfolds; flexed arm (GTH_FARM) and calf girth (GTH_CLF); and humerus (BRDTH_HUM) and femur breadth (BRDTH_FEM)

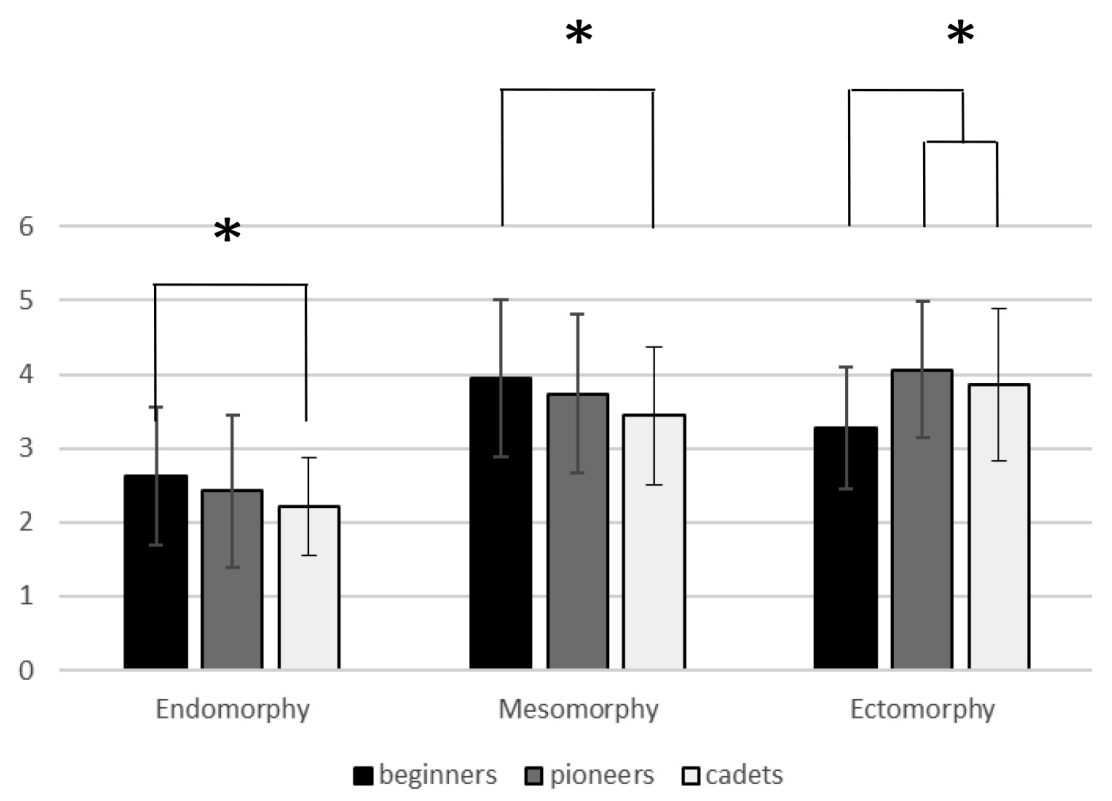

Fig. 1. Somatotype values and differences between different age categories of young soccer players assigned to three groups (beginners, pioneers and cadets). 
between beginners and cadets. Similarly, the main effect was significant regarding ectomorphy $(\mathrm{F} 10,535=5.822, \mathrm{p}<$ $0.001, \eta 2=0.071)$, while particular differences were identified between beginners and the other two groups, as can be seen at Figure 1.

We noticed that in the endomorphic component, soccer youngsters had the most subcutaneous fatty tissue, which decreased over time, and by the time they reached the age of cadets, it was at its lowest value. A higher fat percentage correlates with poorer physical performance (Gil et al., 2007a,b). This data is expected because, over the years, training becomes more frequent, more extensive and intense, so the loss of subcutaneous fat tissue is a normal and desirable effect of organized and systematic training. Nikolaidis \& Vassilios Karydis had similar results on the endomorphic component, while for the mesomorphic component, it was not the case. In the mesomorphic component, there was a completely unexpected surplus. The greatest amount of muscle tissue had the youngest soccer players whose value decreased with years of training, while the lowest values on this component had cadets.

In similar research, in various sports cadets were expected to have larger values in the mesomorphic components than younger age groups (Claessens et al., 1999), so the collected result of the mesomorphic component in this paper should be taken with reserve. As far as the ectomorphic components are concerned, the means do not follow linear trend with age as opposed to the first two components. It can be observed that the lowest score was within the beginners group, the highest score was with the pioneers, and the cadets had a score between the two groups.

\section{CONCLUSION}

Since measurements were taken in a relatively large sample of young soccer players, the established somatotype values can also serve as reference values for the observed age groups. During adolescence, soccer players present significant differences in terms of somatotype components. The observed differences indicate the existence of nonlinear and complex dynamics of interactions of somatotype components, not only under the influence of soccer training, but also under the influence of growth and development. These results can contribute to understanding the interaction and dynamics of somatotypic components of different generations of young soccer players. The results also provide the relevant information necessary for the precise identification of morphological characteristics in young soccer players as well as the modelling of the training process aimed at maximizing the playing potentials and competitive outcomes. Considering the results in differences between somatotypes, more attention should be placed on the selection and training of the young soccer player based on the somatotype characteristics.

SIVRIC, H.; RADA, A. \& MANDIC, J. P. Diferencias de somatotipo en jugadores jóvenes de fútbol: Un enfoque cronológico basado en la edad. Int. J. Morphol., 36(4):1275-1279, 2018.

RESUMEN: El objetivo de esta investigación fue identificar las diferencias de somatotipo entre las diferentes categorías de edad de los jugadores de fútbol jóvenes. De acuerdo con el objetivo, una muestra de 274 jóvenes futbolistas se dividió en tres grupos (principiantes $\mathrm{N} 1=48$, pioneros $\mathrm{N} 2=111$ y cadetes $\mathrm{N} 3=$ 115). Los somatotipos se evaluaron usando el método Heath-Carter. La confiabilidad de los datos obtenidos fue satisfactoria (rango de error técnico de medición [TEM]: 1,11-4,11, rango de coeficiente de variación [CV]: 0,03-0,09). Un ANOVA de un solo sentido, junto con la corrección de Bonferroni, reveló diferencias significativas entre los grupos en todos los componentes del somatotipo. Los resultados indicaron que los jugadores más jóvenes tenían un componente endomórfico más pronunciado $(\mathrm{p}<0.05)$, que disminuyó con años de entrenamiento, y el componente ectomórfico se hizo más evidente en los pioneros, pero luego disminuyó nuevamente. Además, con años de entrenamiento, el componente mesomórfico se volvió menos pronunciado. Las diferencias observadas indicaron la existencia de dinámicas de interacción no lineal y compleja de los componentes del somatotipo que no solo están bajo la influencia del entrenamiento de fútbol, sino también del crecimiento y desarrollo. Estos resultados pueden contribuir a la comprensión de las interacciones y la dinámica de los componentes del somatotipo de diferentes generaciones de jugadores de fútbol jóvenes. Los resultados también proporcionan información relevante necesaria para la identificación precisa de las características morfológicas de los jugadores jóvenes de fútbol, así como la modelización del proceso de entrenamiento destinado a maximizar el potencial de juego y los resultados competitivos.

PALABRAS CLAVE: Características antropométricas; Morfología; Heath-Carter; Selección.

\section{REFERENCES}

Arden, N. K. \& Spector, T. D. Genetic influences on muscle strength, lean body mass, and bone mineral density: a twin study. J. Bone Miner. Res., 12(12):2076-81, 1997.

Carter, J. E. L. \& Heath, B. H. Somatotyping. Development and Applications. Cambridge, Cambridge University Press, 1990.

Carter, J. E.; Ackland, T. R.; Kerr, D. A. \& Stapff, A. Somatotype and size of elite female basketball players. J. Sports Sci., 23(10):1057-63, 2005.

Claessens, A. L.; Lefevre, J.; Beunen, G. \& Malina, R. M. The contribution of anthropometric characteristics to performance scores in elite female gymnasts. J. Sports Med. Phys. Fitness, 39(4):355-60, 1999.

Gil, S. M.; Gil, J.; Ruiz, F.; Irazusta, A. \& Irazusta, J. Anthropometrical 
characteristics and somatotype of young soccer players and their comparison with the general population. Biol. Sport, 27(1):17-24, 2010.

Gil, S. M.; Gil, J.; Ruiz, F.; Irazusta, A. \& Irazusta, J. Physiological and anthropometric characteristics of young soccer players according to their playing position: relevance for the selection process. J. Strength Cond. Res., 21(2):438-45, 2007a.

Gil, S.; Ruiz F.; Irazusta A.; Gil, J. \& Irazusta J. Selection of young soccer players in terms of anthropometric and physiological factors. J. Sports Med. Phys. Fitness, 47(1):25-32, 2007b.

Gontarev, S.; Kalac, R.; Zivkovic, V.; Ameti, V. \& Redjepi, A. Anthropometrical characteristics and somatotype of young Macedonian soccer players. Int. J. Morphol., 34(1):160-7, 2016.

Hazir, T. Physical characteristics and somatotype of soccer players according to playing level and position. J. Hum. Kinet., 26:83-95, 2010.

Hernández-Camacho, J. D.; Fuentes-Lorca, E. \& Moya-Amaya, H. Anthropometric characteristics, somatotype and dietary patterns in youth soccer players. Rev. Andal. Med. Deporte, 10(4):192-6, 2017.

Hopkins, W. G. Measures of reliability in sports medicine and science. Sports Med., 30(1):1-15, 2000

Karlsson, K. M.; Karlsson, C.; Ahlborg, H. G.; Valdimarsson, O.; Ljunghall, S. \& Obrant, K. J. Bone turnover responses to changed physical activity. Calcif. Tissue Int., 72(6):675-80, 2003.

Mészáros, J.; Mohácsi, J.; Szabó, T. \& Szmodis, I. Anthropometry and competitive sport in Hungary. Acta Biol. Szeged., 44(1-4):189-92, 2000.

Nikolaidis, P. T. \& Vassilios Karydis, N. Physique and body composition in soccer players across adolescence. Asian J. Sports Med., 2(2):75-82, 2011.

Orhan, O.; Sagir, M. \& Zorba, E. Comparison of somatotype values of football players in two professional league football teams according to the positions. Coll. Antropol., 37(2):401-5, 2013.

Perroni, F.; Vetrano, M.; Camolese, G.; Guidetti, L. \& Baldari, C. Anthropometric and somatotype characteristics of young soccer players: Differences among categories, subcategories, and playing position. $J$. Strength Cond. Res., 29(8):2097-104, 2015.

Sedeaud, A.; Marc, A.; Schipman, J.; Schaal, K.; Danial, M.; Guillaume M.; Berthelot, G. \& Toussaint, J. F. Secular trend: morphology and performance. J. Sports Sci., 32(12):1146-54, 2014.

Shephard, R. J. Biology and medicine of soccer: an update. J. Sports Sci., 17(10):757-86, 1999

Sutton, L.; Scott, M.; Wallace, J. \& Reilly, T. Body composition of English Premier League soccer players: influence of playing position, international status, and ethnicity. J. Sports Sci., 27(10):1019-26, 2009.

\section{Corresponding author: \\ Hrvoje Sivric \\ College of Slavonski Brod \\ Dr. Mile Budaka 1 \\ 35000 Slavonski Brod \\ CROATIA}

Email: hrvoje.sivric@vusb.hr

Received: 24-05-2018

Accepted: 07-08-2018 